\title{
B-Galactosidase and Alkaline Phosphatase Do Not Become Extracellular When Fused to the Amino-terminal Part of Colicin N
}

\author{
By ANTHONY P. PUGSLEY ${ }^{*}$ and STEWART T. COLE 2 \\ Unités de Génétique Móleculaire ${ }^{1}$ et des Applications de Genie Génetique ${ }^{2}$, Institut Pasteur, \\ 28 rue du Dr Roux, 75724 Paris Cedex 15, France
}

(Received 5 December 1985; revised 17 March 1986)

\begin{abstract}
A series of plasmids encoding hybrid proteins comprising various lengths of the $\mathrm{NH}_{2}$-terminal region of colicin $\mathrm{N}$ coupled to almost complete $\beta$-galactosidase or alkaline phosphatase polypeptides was constructed by transposon mutagenesis of ColN plasmid derivatives. Synthesis of the hybrid proteins, like that of colicin $\mathrm{N}$ itself, was regulated by the SOS response. Large quantities of the hybrid proteins accumulated in the cytoplasm ( $\beta$-galactosidase) or particulate fractions (alkaline phosphatase). When the gene fusions were expressed in cells that were producing colicin E2 and expressing the ColE2 lysis gene, only very low levels of the hybrid proteins were found in the medium. The results suggest that the amino-terminal part of colicin $N$ does not contain sufficient biochemical information to promote the release of the hybrid proteins into the medium.
\end{abstract}

\section{INTRODUCTION}

An increasing awareness that many different Gram-negative bacteria can secrete proteins into the growth medium, coupled with the potential use of protein secretion in biotechnology, has catalysed research into the ways in which polypeptides are translocated across the twin barriers created by the inner (cytoplasmic) and outer membranes (reviewed by Pugsley \& Schwartz, 1985). The secretion of some proteins such as cholera toxin or pseudomonas exotoxin A (Hirst et al., 1984; Lory et al., 1983) seems to represent an extension of the signal peptide pathway by which Gram-negative bacteria export most of their periplasmic or outer membrane proteins. This is by no means always the case, however, as alternative routes are used in the secretion of haemolysin (Felmlee et al., 1985) or colicins (Pugsley, 1984b) by Escherichia coli K12.

Colicins are encoded by plasmids, which, in most cases, carry a 'lysis' gene whose expression is essential for colicin efflux and which, like the colicin structural gene, is regulated by the SOS response (Oudega et al., 1982; Pugsley \& Schwartz, 1983; Jakes \& Zinder, 1984; Lawrence \& James, 1984; Pugsley, 1984a; Cavard et al., 1985; Zhang et al., 1985). The product of the lysis gene is a small envelope protein which stimulates an envelope phospholipase, probably to increase outer membrane permeability (Pugsley \& Schwartz, 1984). The macropermeability of the inner membrane is not substantially affected by the activation of phospholipase (Pugsley \& Rosenbusch, 1981) and the release of colicins from the cytoplasm, where they accumulate in large amounts (Cavard et al., 1984), is not accompanied by the release of other cytoplasmic proteins. Specific regions of the colicin polypeptide might therefore be required to promote their release. However, lysis proteins encoded by different Col plasmids have highly conserved amino acid sequences (Cavard et al., 1985; Chan et al., 1985; Cole et al., 1985; Hakkaart et al., 1981; Watson et al., 1984), and yet can promote the release of heterologous colicins (Pugsley \&

Abbreviations: COLN-BGAL, colicin N- $\beta$-galactosidase hybrid polypeptide; COLN-PHOA, colicin Nalkaline phosphatase hybrid polypeptide. 
Schwartz, 1983), which suggests that they may not interact directly with the colicins(s) to promote their transfer across the cytoplasmic membrane.

Previous studies in our laboratories showed that truncated colicins containing the aminoterminal $70 \%$ of the $39000 M_{\mathrm{r}}$ colicin N or the amino-terminal $50 \%$ of the $62000 M_{\mathrm{r}}$ colicin E2 were efficiently released from cells expressing the lysis gene (Pugsley, 1984a; Cole et al., 1985). This suggested that any sequence required for release would be located in the $\mathrm{NH}_{2}$-part of the colicin polypeptides. This, in turn, raised the possibility of genetically fusing the $\mathrm{NH}_{2}$-terminal parts of these colicins to other polypeptides, thereby creating hybrid proteins which could be released from the cells upon expression of the lysis gene. Colicin $\mathrm{N}$ seemed particularly well suited for this purpose because it is smaller than most other colicins, and because $\operatorname{Tn} 5$ insertions in the colicin $\mathrm{N}$ structural gene, cna, lead to the production of stable, truncated colicin $\mathbf{N}$ polypeptides (Pugsley, 1984a). In this report, we describe the construction and analysis of hybrid genes containing varying lengths of cna coupled to 'lac $Z$, which codes for the soluble cytoplasmic enzyme $\beta$-galactosidase, or to 'phoA, which codes for a soluble, non-exported variant of the normally periplasmic alkaline phosphatase.

\section{METHODS}

Growth media. L broth and L broth agar (Miller, 1972) were used throughout. Antibiotics were used at the following concentrations $\left(\mu \mathrm{g} \mathrm{ml}^{-1}\right)$ : Ap, 200; Km, 50; Tc, 15. Mitomycin $\mathrm{C}$ was used at $0.5 \mu \mathrm{g} \mathrm{m}^{-1}$ in broth cultures and at $0.1 \mu \mathrm{g} \mathrm{ml}^{-1}$ in agar media. In some cases, $20 \mathrm{mM}-\mathrm{MgSO}_{4}$ was added to broth cultures to suppress partial lysis due to lysis gene expression. All cultures were grown aerobically at $37^{\circ} \mathrm{C}$.

Strains, plasmids and construction of gene fusions. The $E$. coli $\mathrm{K} 12$ strains and plasmids used in this study are listed in Table 1. The plasmids used to construct gene fusions were derived from pColN-284 (Pugsley, 1984a), or from pCHAP4, a ColN plasmid found in a new $\mathrm{Col}^{+}$isolate from the River Rhine in Switzerland. pAPIP401, derived from pColN-284 (Pugsley, 1984a), and pCHAP12, derived from pCHAP4 (Fig. 1), were used for constructing gene fusions.

lac $Z$ gene and operon fusions were obtained by miniMu d transposition as described by Castilho $e t$ al. (1984) using strains POII1681TR or POIII734TR (gene fusions) and POI1681TR or POI1734TR (operon fusions). pAPIP401 was introduced into these strains by transformation (Maniatis et al., 1982) with selection for $\mathrm{Ap}^{\mathrm{R}}$. The transformants were then thermally induced to produce phage particles (Castilho et al., 1984), which were used to infect strain PAP713 with selection for $\mathrm{Ap}^{\mathrm{R}} \mathrm{Km}^{\mathrm{R}}$ on $\mathrm{L}$ agar plates. Randomly-selected colonies were tested for colicin production in patch tests (Pugsley, 1985) and for their LacZ phenotype on $\mathrm{L}$ agar + ampicillin +5 bromo-4-indolyl $\beta$-D-galactoside $(\mathrm{XGal}) \pm$ mitomycin C. $\mathrm{Lac}^{+}$(blue) $\mathrm{Col}^{-}$clones were retained for further analysis.

Alkaline phosphatase gene fusions were obtained by infecting strain PAP103 (pCHAP12 pAPIP502) with TnphoA as described previously for Tn5 (Pugsley \& Schwartz, 1983). Plasmids obtained by the method of Holmes \& Quigley (Maniatis et al., 1982) from independently-mutagenized cultures were used to transform strain PAP488 with selection for $\mathrm{Ap}^{\mathrm{R}} \mathrm{Km}^{\mathrm{R}}$ on $\mathrm{L}$ agar +5 -bromo-4-chloro-3-indolyl phosphate. Transformants which produced blue $\left(\mathrm{PhoA}^{+}\right)$colonies were tested for colicin production in patch tests. Plasmid preparations from cultures of the

\section{Table 1. Escherichia coli K12 strains and plasmids}

Strain/plas
PAP103
PAP488
PAP713
BZB1011
PAP308
PAP151
pAPIP401
pCHAP12
pAPIP502
pMM100
pCH2

Strain/plasmid

Characteristics

$\Delta($ lac-pro $)$

PAP103 rpsL

araD139 $\Delta$ (ara-leu) $7679 \Delta$ (pro-arg-lac)

XIII ompF $\mathrm{Mu}^{+}$rpsL

gyrA

BZB1011 ompF

BZB1011 rbs::Tn10 phos

ori pBR322 $\mathrm{bla}^{+} \mathrm{Cna}^{+} \mathrm{cni}^{+} \mathrm{Cnl}^{+}$

ori pUC9 $\mathrm{bla}^{+} \mathrm{cna}^{+} \mathrm{cni}^{+} \mathrm{cnl}^{+}$

$\mathrm{F}^{\prime}$ pro $^{+}$SlacZM15 lac ${ }^{91} \mathrm{Tn} 10$

ori $\mathrm{pACYC} 184$ tet $^{+}$lac $^{91}$

ori $\mathrm{pBR} 322$ tet $t^{+} \Phi($ bla-phoA $)$

\section{Source/reference}

Laboratory strain

Laboratory strain

Laboratory strain*

Laboratory strain

Laboratory strain

Laboratory strain

Pugsley (1984a)

Fig. 1

Pugsley \& Schwartz (1983)

M. Lavina $\dagger$

Hoffman \& Wright (1985)

* Derived from strain MM8820 (Castilho et al., 1984).

† M. Lavina, Hopital Ramon y Cajal, Madrid, Spain. 
$\mathrm{Col}^{-} \mathrm{PhoA}^{+}$clones repeatedly gave heterogeneous patterns when examined by agarose gel electrophoresis (Maniatis et al., 1982). This was apparently due to a high frequency of spontaneous deletion formation, which we overcame by deleting DNA between the BamHI site within TnphoA and the BamHI site at the junction between the pCHAP4 DNA and pUC9 DNA in pCHAP12 (Fig. 1). This removed IS50R, the probable cause of the deletions.

Plasmid analysis. Plasmids were digested with restriction endonucleases and ligated with T4 DNA ligase as described by Maniatis et al. (1982). Tris/acetate-buffered agarose gels containing $0 \cdot 7-1 \cdot 0 \%$ agarose were used for plasmid analysis (Maniatis et al., 1982), and were calibrated with DNA fragments of known sizes.

Cell fractionation and protein analysis. Cell-free and cell-associated proteins were precipitated with TCA (Pugsley \& Schwartz, 1984) and examined by SDS-PAGE essentially as described by Pugsley \& Schnaitman (1979) using Tris/glycine buffers with $10 \%(\mathrm{w} / \mathrm{v})$ acrylamide $/ 0 \cdot 13 \%$ bisacrylamide gels. Proteins were stained with Coomassie Blue. Cell-associated enzymes were released by sonication at $4{ }^{\circ} \mathrm{C}$. Osmotic shock was effected as described by Nossal \& Heppel (1966). Membrane fractions were obtained by centrifuging sonicated cells at $46000 \mathrm{~g}$ or $130000 \mathrm{~g}$ for $2 \mathrm{~h}$. Enzymes were assayed according to Miller (1972; $\beta$-galactosidase), Brockman \& Heppel (1968; alkaline phosphatase) or Raibaud et al. (1984; amylomaltase). Colicin was assayed as described previously (Pugsley \& Rosenbusch, 1981).

\section{Colicin $N-\beta$ galactosidase fusion proteins}

Fusions between cna and lac $Z$ genes. These were obtained by mutagenizing plasmid pAPIP401 with miniMu dII 1681 or miniMu dII 1734 (Methods). Approximately $25 \%$ of the $\mathrm{Ap}^{\mathrm{R}} \mathrm{Km}^{\mathrm{R}}$ transfectants were $\mathrm{Col}^{-}$in patch tests and, of these, $15 \%$ produced pale or moderately blue colonies on LA plates containing XGal and dark blue colonies on the same medium containing $0.1 \mu \mathrm{g}$ mitomycin $\mathrm{C} \mathrm{ml}^{-1}$ to induce $c n a$ expression. This was close to the expected frequency $(17 \%)$ for the random insertion of miniMu dII transposons giving in-frame lac $Z$ gene fusions. The initial stages of selection were done in the absence of cna induction by mitomycin $\mathrm{C}$. All resulting clones grew normally in $\mathrm{L}$ broth supplemented with $0.5 \mu \mathrm{g}$ mitomycin $\mathrm{C} \mathrm{ml}^{-1}$, indicating that expression of the $\operatorname{lac} Z$ gene fusions was not detrimental to cell viability.

A total of 11 independent $\mathrm{Lac}^{+} \mathrm{cna}-\mathrm{lac} Z$ gene fusion plasmids were further analysed. The location of the fusion site in pAPIP401 was determined by digestion with restriction endonucleases; the results in Table 2 show the positions of the insertion sites relative to coordinate 0 , the calculated translation initiation site of cna (Fig. 1 and Pugsley, 1984a). Mitomycin $\mathrm{C}$ induction of strains carrying these plasmids resulted in the production of large amounts of presumed cna-lacZ gene products (COLN-BGAL) (Fig. 2) whose estimated $M_{\mathrm{r}}$ values were similar to those predicted from the length of $c n a$ present in the hybrid genes (Table 2). Only in one case were we unable to detect a COLN-BGAL polypeptide (Table 2).

As predicted from the results of plate tests (see above), $\beta$-galactosidase activity increased when cells harbouring the gene fusion plasmids were grown in the presence of mitomycin $\mathrm{C}$ (Table 2). Variations in basal and induced levels of $\beta$-galactosidase activity were observed both with $c n a-l a c Z$ gene fusions and with $c n a-l a c Z$ operon fusions obtained by the insertion of miniMu dI1681 or miniMu dI1728 into pAPIP401 (Table 2). There was no obvious correlation between fusion site and $\beta$-galactosidase activity other than the somewhat higher recovery of $\beta$ galactosidase with lac $Z$ gene fusions in the extreme $5^{\prime}$ end of cna (Table 2).

Regulation of cna-lacZ expression. The results of a detailed analysis of the SOS control of cnalac $Z$ expression confirmed that non-induced and mitomycin $\mathrm{C}$-induced cna-lac $Z$ expression are both dependent on the products of the $\operatorname{lex} A$ and $\operatorname{rec} A$ genes (see Pugsley, 1984a), and are independent of the $\operatorname{rec} B, \operatorname{rec} F, u v r A$ and $u v r B$ gene products (data not shown). This is entirely consistent with the control of $c n a$ expression at the transcription level via the classical SOS regulatory circuit (reviewed by Walker, 1984).

Subcellular location of the cna-lacZ gene products. The insertion of miniMu $\mathrm{d}$ transposons into cna exerted a polar effect on the expression of the down-stream lysis gene, cril (Pugsley, 1984a and Fig. 1). Cells carrying cna-lacZ fusion plasmids therefore did not lyse or release proteins when induced with mitomycin C. Less than $5 \%$ of the $\beta$-galactosidase activity was recovered 
Table 2. Characterization of cna-lacZ gene and operon fusions in derivatives of strains $P A P 488$ (wild-type) or PAP489 (recA) carrying pAPIP401 cna : :miniMu d plasmids

\begin{tabular}{|c|c|c|c|c|c|c|}
\hline \multirow[b]{2}{*}{$\begin{array}{c}\text { Allele } \\
\text { no. }\end{array}$} & \multirow[b]{2}{*}{$\begin{array}{c}\text { Fusion } \\
\text { site }^{*} \\
\text { (bp) }\end{array}$} & \multirow[b]{2}{*}{$\begin{array}{c}\text { Fusion } \\
\text { protein } \dagger \\
\left(10^{-3} \times M_{\mathrm{r}}\right)\end{array}$} & \multirow[b]{2}{*}{$\begin{array}{c}\text { Colicin } \\
\text { in fusion } \\
\text { protein }{ }^{\dagger} \\
\left(10^{-3} \times M_{\mathrm{r}}\right)\end{array}$} & \multicolumn{3}{|c|}{$\beta$-Galactosidase (Miller U) $\ddagger$} \\
\hline & & & & 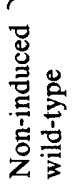 & 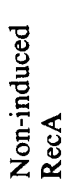 & 异莒 \\
\hline \multicolumn{7}{|c|}{ Gene fusions } \\
\hline 4 & 140 & 121 & 1 & 886 & 96 & 10600 \\
\hline 2 & 250 & 123 & 3 & 837 & 25 & 25100 \\
\hline 9 & 340 & ND & ND & 303 & 115 & 1800 \\
\hline 5 & 340 & 124 & 4 & 184 & 44 & 5520 \\
\hline 18 & 460 & 129 & 9 & 150 & 5 & 4420 \\
\hline 15 & 480 & 137 & 17 & 123 & 6 & 1840 \\
\hline 14 & 540 & 137 & 17 & 167 & 10 & 3170 \\
\hline 3 & 620 & 147 & 27 & 128 & 33 & 4860 \\
\hline 1 & 660 & 149 & 29 & 324 & 100 & 8740 \\
\hline 19 & 880 & 154 & 34 & 208 & 9 & 4160 \\
\hline 13 & 1000 & 156 & 36 & 201 & 20 & 5200 \\
\hline \multicolumn{7}{|c|}{ Operon fusions } \\
\hline 65 & 20 & & & 237 & 22 & 4000 \\
\hline 62 & 240 & & & 544 & 82 & 13000 \\
\hline 70 & 340 & & & 391 & 66 & 10900 \\
\hline 66 & 640 & & & 544 & 82 & 11420 \\
\hline 63 & 840 & & & 467 & 51 & 7900 \\
\hline
\end{tabular}

ND, Not detected.

* The site of the miniMu d insertion in pAPIP401 was determined by restriction endonuclease digestion based on the known restriction maps of pAPIP401 and the miniMu d transposons (Fig. 1 and Castilho et al., 1984). The length of the cna gene was estimated to be $1080 \mathrm{bp}$ (Pugsley, 1984a); the fusion sites are represented relative to the estimated translation start point of cna.

$\dagger$ The size of the fusion protein was estimated by SDS-PAGE. The length of colicin $\mathbf{N}$ polypeptide was determined by subtracting 116000 ( $\beta$-galactosidase) +4000 (the peptide encoded by the 117 bp of Mu DNA in each fusion gene; Castilho et al., 1984). Colicin $\mathrm{N}$ is 39000 .

$\ddagger \beta$-Galactosidase activities were determined in cultures incubated to $\operatorname{OD}_{600} 0.2$ before the addition of $0.5 \mu \mathrm{g}$ mitomycin $\mathrm{C} \mathrm{ml}^{-1}$, and then incubated for a further three generations. Results are means of three assays done with the same culture.

from the culture medium, and about $3 \%$ and $10 \%$ respectively of the cell-associated activity was recovered from the membrane fraction or was released by cold osmotic shock. These results are in agreement with others showing that colicins accumulate in the cytoplasm of producing cells (Cavard et al., 1984).

Previous experiments indicated that pCo1E2-P9 could complement $c n l:: \operatorname{Tn} 5$ mutations in derivatives of pAPIP401, leading to the efficient release of colicin $\mathrm{N}$ and colicin E2 [unpublished data, see Pugsley \& Schwartz (1983) for similar experiments with other Col plasmids]. We therefore transformed strains carrying pAPIP401 cna::miniMu dII plasmids with pColE2-P9 and studied the location of the COLN-BGAL hybrids and colicin E2 during growth in the presence of mitomycin $\mathrm{C}$. The cells partially lysed and released colicin E2 within $2 \cdot 5-3 \mathrm{~h}$ after the addition of mitomycin $\mathrm{C}$ to the culture, as is normal for cells carrying pColE2P9 (Pugsley \& Schwartz, 1984), but $\geqslant 93 \%$ of the $\beta$-galactosidase activity remained cellassociated. Less than $5 \%$ of this cell-associated activity was recovered from the membrane fraction of sonically disrupted cells. The distribution of the COLN-BGAL polypeptide, as detected by SDS-PAGE, was similar to that of the $\beta$-galactosidase activity (data not shown). We concluded that COLN-BGAL hybrids were cytoplasmic, and that they could not be released from producing cells through the colicin efflux pathway. 


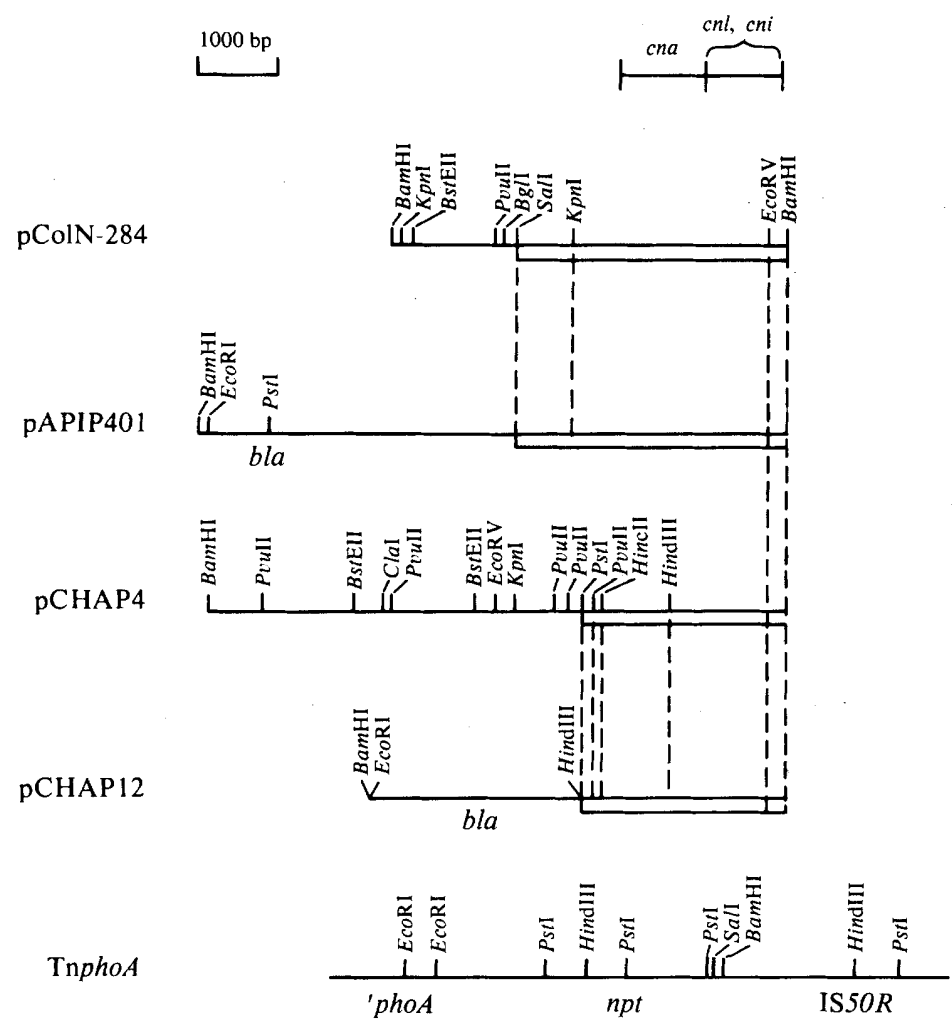

Fig. 1. Physical maps of plasmids used for constructing $c n a-l a c Z$ and $c n a-p h o A$ gene fusions. The maps of pColN-284 and pAPIP401 are based on those published previously (Pugsley, 1984a), with additional sites for BstEII, EcoRV and KpnI restriction endonucleases. The boxed area represents the region of pColN-284 which was subcloned into pBR322 to give pAPIP401 (Pugsley, 1984a). The physical map of pCHAP4 was constructed after analysis of fragments generated by digestion with various restriction endonucleases. The enzymes $B g I$, $S a I, E c o$ RI, $B g l I I$ and $S a c I$ did not cleave pCHAP4 DNA. Plasmid pCHAP12 was constructed by subcloning the smaller PstI-BamHI fragment of pCHAP4 (boxed region) into pUC9 cleaved with the same enzymes. The $c n a-c n l$ operon in pCHAP12 is in the same orientation as the lac $Z$ promoter. The location of the $c n a$ (colicin $N$ ), cni (immunity) and $c n l$ (lysis) genes in the boxed regions is shown at the top right of the figure (Pugsley, 1984a). The physical map of Tnpho $A$ is based on that of Manoil \& Beckwith (1985), and is shown in the orientation in which it was found in pCHAP12::TnphoA plasmids.

\section{Colicin $N$-alkaline phosphatase fusion proteins}

Fusions between the cna and phoA genes. The transposon TnphoA carries a 'phoA gene lacking sequences that code for the signal peptide. The insertion of TnphoA into the coding sequence of a gene can therefore create an in-frame fusion leading to the production of alkaline phosphatase. Export signals in the product of the target gene may induce the export of the hybrid protein (Manoil \& Beckwith, 1985). cna-phoA gene fusions were obtained by TnphoA mutagenesis of pCHAP12, in which cna should be transcribed from both lacZ and cna promoters (Fig. 1). Twelve independent $\mathrm{Col}^{-} \mathrm{PhoA}^{+}$clones yielded four different classes of cna-phoA fusion plasmids (Table 3). The initial plasmids were stabilized by deleting IS50R (Methods), and then transferred to strain PAP488. The resulting strains all produced relatively high amounts of alkaline phosphatase activity [yields were similar to those obtained with strains carrying $\mathrm{pCH} 2$ (Hoffman \& Wright, 1985)], and three of them produced large amounts of a novel polypeptide (COLN-PHOA) whose apparent $M_{\mathrm{r}}$ was in good agreement with that predicted for the corresponding cna-phoA gene product (Fig. 3, Table 3). Mitomycin C induction resulted in only 


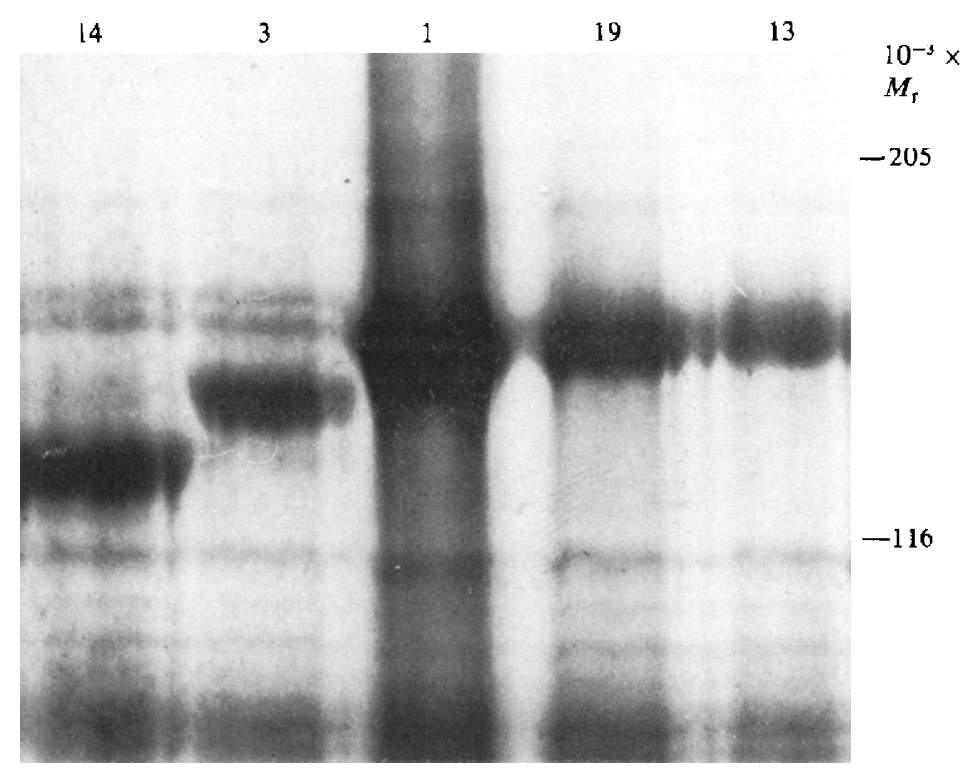

Fig. 2. Polypeptides encoded by selected cna-lac $Z$ gene fusions. Cultures of strains carrying pAPIP401:: miniMu dII plasmids were grown for three generations in L broth containing $0.5 \mu \mathrm{g}$ mitomycin $\mathrm{C} \mathrm{ml}^{-1}$. The cells were then lysed by sonication in gel sample buffer and run on an SDSPAGE gel. Only that part of the gel displaying the hybrid proteins is shown. The numbers at the top are the allele numbers of the respective $c n a-l a c Z$ gene fusions. The $M_{\mathrm{r}}$ markers were $\beta$-galactosidase (116000) and myosin (205000).

Table 3. Characteristics of cna-phoA gene fusions in derivatives of strain PAP488 or PAP488(pMM100) carrying pCHAP12::TnphoA

\begin{tabular}{|c|c|c|c|c|c|c|c|c|}
\hline \multirow[b]{2}{*}{$\begin{array}{c}\text { cna-phoA } \\
\text { allele } \\
\text { no. }\end{array}$} & \multirow[b]{2}{*}{$\begin{array}{c}\text { No. } \\
\text { isolated }\end{array}$} & \multirow[b]{2}{*}{$\begin{array}{l}\text { Fusion } \\
\text { site* }^{*} \\
\text { (bp) }\end{array}$} & \multirow[b]{2}{*}{$\begin{array}{c}\text { Fusion } \\
\text { protein } \dagger \\
\left(10^{-3} \times M_{\mathrm{r}}\right)\end{array}$} & \multirow[b]{2}{*}{$\begin{array}{c}\text { Colicin in } \\
\text { in fusion } \\
\text { protein } \\
\left(10^{-3} \times M_{\mathrm{r}}\right)\end{array}$} & \multicolumn{4}{|c|}{$\begin{array}{l}\text { Alkaline phosphatase } \neq \\
\text { (U per } \mathrm{OD}_{600} \text { unit) }\end{array}$} \\
\hline & & & & & 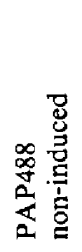 & 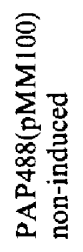 & 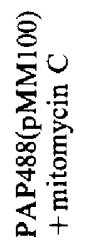 & 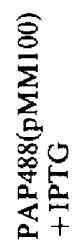 \\
\hline 101 & 8 & 200 & $\mathrm{ND}$ & ND & 160 & 6 & 190 & \\
\hline 104 & 1 & 250 & 56 & 9 & 21 & 5 & 40 & \\
\hline 112 & 2 & 500 & 64 & 17 & 446 & 8 & 504 & \\
\hline 105 & 1 & 800 & 76 & 29 & 219 & 6 & 276 & \\
\hline
\end{tabular}

ND, not detected.

* Positions of the TnphoA inserts are relative to the estimated translation start point of the cna gene (Pugsley, $1984 a)$.

† The $M_{\mathrm{r}}$ of the hybrid protein was calculated from its migration in SDS-PAGE relative to proteins of known $M_{\mathrm{r}}$. The amount of colicin N in the hybrid was calculated by deducting the $M_{\mathrm{r}}$ of alkaline phosphatase (47000) from that of the hybrid. Colicin $\mathrm{N}$ is 39000 .

$¥$ Alkaline phosphatase activities were calculated in the same way as those of $\beta$-galactosidase (Miller, 1972). Non-induced cultures were at steady state during exponential growth. Induced cultures were growing in the presence of $0.5 \mu \mathrm{g}$ mitomycin $\mathrm{C} \mathrm{m}^{-1}$ or $1 \mathrm{mM}$-isopropyl $\beta$-D-galactoside. PAP488(pCH2) produced $300-350 \mathrm{U}$ alkaline phosphatase under the same conditions. Strain PAP488 itself produced $<1 \mathrm{U}$ alkaline phosphatase. The results are means of three assays done with the same culture. Activities varied in different experiments by as much as $30 \%$. 
A

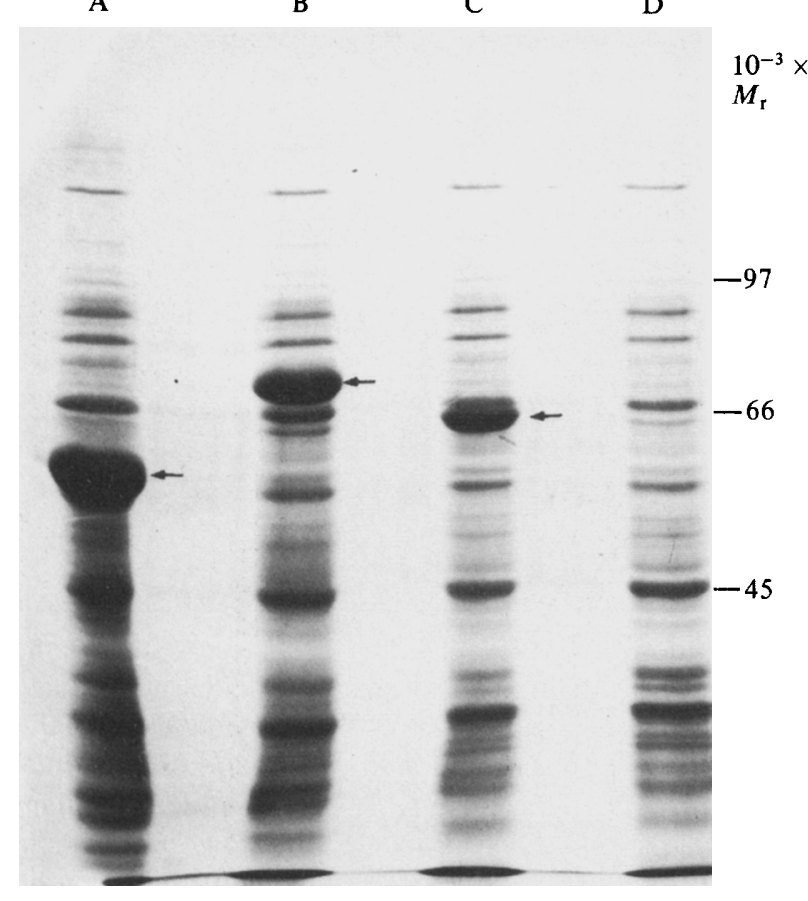

Fig. 3. Total cell proteins of PAP488(pCHAP12::TnphoA) derivatives grown in L broth. Cells were lysed by sonication in gel sample buffer and the proteins separated by SDS-PAGE. The samples are equivalent to $150 \mu \mathrm{l}$ of culture at $\mathrm{OD}_{600} 1 \cdot 0$. A, $\Phi(c n a-p h o A) 104 ; \mathrm{B}, \Phi($ cna-phoA $) 105 ; \mathrm{C}$. Ф(cnaphoA $) 112 ; \mathrm{D}, \Phi($ cna-phoA $) 101$. Arrows indicate the putative $c n a-p h o A$ gene products. The $M_{\mathrm{r}}$ marker proteins were bovine serum albumin (66000), phosphorylase $a(97000)$ and ovalbumin (45000).

Table 4. Localization of alkaline phosphatase activity in PAP488 derivatives carrying pCHAP12::ThphoA plasmids with or without $p$ ColE2-P9

\begin{tabular}{|c|c|c|c|c|c|c|c|c|c|}
\hline & & & & Alka & $\begin{array}{l}\text { pho } \\
\text { cent }\end{array}$ & $\begin{array}{l}\text { hata } \\
\text { e of }\end{array}$ & ivity & & \\
\hline & & & & AP48 & & & & $\begin{array}{l}\text { AP4 } \\
\text { (F) }\end{array}$ & \\
\hline & & & & & Soni & ted & & Son & $\overrightarrow{\text { ated }}$ \\
\hline $\begin{array}{c}\text { Allele } \\
\text { no. }\end{array}$ & $\begin{array}{c}\text { Colicin } \\
\text { in fusion } \\
\text { protein } \\
\left(10^{-3} \times M_{\mathrm{r}}\right)\end{array}$ & 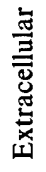 & 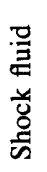 & $\frac{\sqrt{3}}{\stackrel{3}{0}}$ & 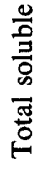 & 葋 & 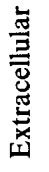 & $\frac{\dddot{2}}{3}$ & 苞 \\
\hline 101 & $6 \S$ & 6 & 43 & 51 & 46 & 54 & 70 & 22 & 8 \\
\hline 104 & 9 & 3 & 18 & 79 & 34 & 66 & 22 & 48 & 30 \\
\hline 112 & 17 & 4 & 13 & 79 & 29 & 71 & 43 & 49 & 8 \\
\hline 105 & 29 & 6 & 32 & 62 & 45 & 55 & 45 & 41 & 14 \\
\hline
\end{tabular}

* See Table 3 for specific activities; results are from a single experiment.

$\dagger$ In cultures grown to $\mathrm{OD}_{600} 1.0$ without induction.

$\ddagger$ In cultures grown for $5 \mathrm{~h}$ in L broth containing mitomycin C, $80-90 \%$ of the colicin E2 activity was extracellular at this time.

$\S$ Estimated from position of TnphoA in $c n a$ gene. COLN-PHOA polypeptide was not detected in strains carrying this allele (see Table 3 ). 


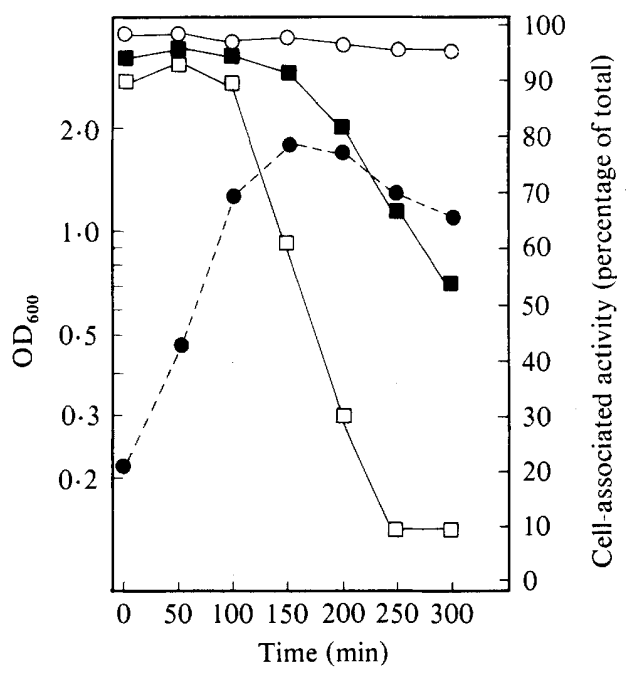

Fig. 4. Growth and protein release by strain PAP488(pColE2-P9 pCHAP12::TnphoA112) growing in $\mathrm{L}$ broth containing $0.4 \%$ maltose to induce synthesis of amylomaltase. Enzyme activities $(O$, amylomaltase; $\square$, alkaline phosphatase; $\square$, colicin E2) are the amounts which were cell-associated expressed as a percentage of the total activity present in the culture. The culture was induced with mitomycin $\mathrm{C}\left(0.5 \mu \mathrm{g} \mathrm{m}^{-1}\right)$ at $0 \mathrm{~min}$, and changes in culture density $\left(\mathrm{OD}_{600}, O\right)$ were recorded. Results are from a single experiment.

a slight increase in cna-phoA expression. The introduction of pMM100 (lacI $\left.{ }^{\mathrm{q}}\right)$ into these strains reduced cna-phoA expression to basal levels, and restored inducibility by mitomycin $\mathrm{C}$ and by isopropyl $\beta$-D-galactoside (Table 3 and data not shown). These results showed that both cna and lac $Z$ promoters could be active in the pCHAP12::TnphoA derivatives.

The subcellular location of alkaline phosphatase activity and of COLN-PHOA polypeptide was determined by subjecting cells to osmotic shock to release periplasmic proteins, or by sonicating them and then centrifuging at high speed to separate soluble and particulate (membrane) fractions. Between $29 \%$ and $46 \%$ of the activity was detected in the soluble (periplasmic + cytoplasmic) fraction of the sonically-disrupted cells, and $13-43 \%$ of the activity was released by cold osmotic shock (Table 4). Wild-type alkaline phosphatase (strain PAP151) and hybrid $\beta$-lactamase-alkaline phosphatase encoded by the bla-phoA gene fusion in $\mathrm{pCH} 2$ (Hoffman \& Wright, 1985) were almost exclusively soluble and were released by cold osmotic shock. In contrast, the analysis of the protein content of the various cell fractions by SDS-PAGE indicated that COLN-PHOA was located exclusively in the particulate fraction (data not shown). Identical results were obtained when strain PAP308 [ompF; lacking the colicin N receptor protein (Tommassen $e t$ al., 1984)] was used as host for the $c n a-p h o A$ fusion plasmids. These results ruled out possible artifacts caused by the readsorption of released COLN-PHOA by the colicin $\mathrm{N}$ receptor. Possible explanations for the different locations of active alkaline phosphatase and COLN-PHOA polypeptide are given in the Discussion.

Strains carrying cna-phoA fusion plasmids together with pColE2-P9 partially lysed after 2$2.5 \mathrm{~h}$ growth in the presence of mitomycin C. Alkaline phosphatase activity was also detected in the growth medium, although it was released more slowly and less extensively than colicin E2 (Fig. 4 and Table 4). Furthermore, when the protein content of the induced cells and culture medium was examined, the COLN-PHOA polypeptide was found exclusively in the cells, whereas the bulk of the colicin E2 was in the medium (data not shown). Amylomaltase, a maltose-inducible cytoplasmic protein remained wholly cell-associated throughout the period during which colicin was being released from the cells (Fig. 4). 


\section{DISCUSSION}

The data we present here indicate that hybrid proteins containing the $\mathrm{NH}_{2}$-terminal part of colicin $\mathrm{N}$ and almost the entire sequence of alkaline phosphatase or $\beta$-galactosidase can be made in large amounts by $E$. coli $\mathrm{K} 12$ carrying the appropriate fused genes. To our knowledge, this is the first time that such large quantities of colicin fusion proteins have been obtained, although Vernet et al. (1985) have described a colicin E3-insulin hybrid which is synthesized in relatively low amounts, and Yamade \& Nakazawa (1984) have described fusions between the ceaA (colicin E1) and lac $Z$ genes.

None of the COLN-BGAL or COLN-PHOA chimeras were secreted into the growth medium by cells that were actively releasing colicin E2. These results will now be considered in the light of what is already known about the proteins which comprise the hybrids, and of previous attempts to export other $\beta$-galactosidase or alkaline phosphatase hybrids.

The system involved in colicin efflux is completely different from the signal peptidedependent export of periplasmic and outer membrane proteins. Therefore, even though $\beta$ galactosidase apparently cannot be made wholly extracytoplasmic by genetically fusing it to proteins which are made with signal sequences [Pugsley \& Schwartz, 1985; see also Benson et al. (1985) and Tommassen et al. (1985) for further discussion of this point], there was no a priori reason to expect that the same would be true for COLN-BGAL hybrids. However, COLNBGAL hybrids containing almost all of the colicin $\mathrm{N}$ polypeptide were fully retained within the cytoplasm of cells that were releasing colicin.

In choosing the normally periplasmic alkaline phosphatase as an alternative to $\beta$ galactosidase for fusing to colicin $\mathrm{N}$, we hoped to avoid problems caused by the possible inability of the LacZ sequences to cross bacterial membranes. Alkaline phosphatase is enzymically inactive when it remains in the cytoplasm, presumably because the reducing conditions in the cytoplasm prevent the formation of disulphide bridges required to produce active alkaline phosphatase (Michaelis et al., 1983; Hoffman \& Wright, 1985; Manoil \& Beckwith, 1985). We therefore anticipated that COLN-PHOA hybrids would have only low alkaline phosphatase activities because they, like the colicin itself, would accumulate at least transiently in the cytoplasm. To facilitate their detection we used a constitutively expressed cna gene as the target for TnphoA mutagenesis. This approach was successful in that we obtained cna-phoA gene fusions which encoded enzymically-active COLN-PHOA, but the hybrid proteins exhibited several unusual characteristics. The most important of these was that, in three of the four cases studied, the COLN-PHOA polypeptide was detected only in the particulate cell fraction, whereas a substantial amount of the active enzyme was detected in the soluble cell fraction. Thus, the specific activity of the COLN-PHOA hybrids varied according to their location within the producing cells. We suspect that these COLN-PHOA polypeptides were mostly in an aggregated state rather than in the membrane, as is the case with some other over-produced proteins in E. coli (Schoemaker et al., 1985). Active alkaline phosphatase was also present in the soluble cell fraction of cells carrying the (cna-phoA)101 gene fusion, although no COLN-PHOA polypeptide could be detected, presumably because it was proteolytically degraded. Both of these observations could explain why COLN-PHOA polypeptides were not released into the medium even though relatively high levels of alkaline phosphatase activity were detected. Some of these anomalies could have arisen as a consequence of the high level expression of the cna-phoA fusions, or because we only studied potential cna-phoA fusions which encoded active alkaline phosphatase.

An alternative interpretation of our data is that the amino-terminal $70 \%$ colicin $\mathrm{N}$ does not contain all of the signals required for hybrid protein release into the medium. Further studies with different types of colicin gene fusions and with mutationally-altered colicins specifically affected in colicin efflux will be needed to identify sequences involved in the release of colicins from producing cells.

Colicins are translocated into as well as out of $E$. coli cells. The two processes are apparently completely different, although there are some obvious similarities between the mechanisms of colicin uptake and the uptake of nuclear-encoded proteins by mitochondria (Pugsley, 1984b; Hay et al., 1984). Studies of mitochondrial biogenesis have been considerably advanced through 
the use of hybrid proteins (Douglas et al., 1984; Hurt et al., 1984). The COLN-BGAL hybrids that we describe here may be useful for studying the mechanisms of colicin uptake, particularly since colicin $\mathrm{N}$, unlike most other colicins, uses an abundant outer membrane protein as its receptor (Tommassen et al., 1984), thereby increasing the number of colicin molecules that could penetrate into the cell.

The authors are grateful to Colin Manoil (Harvard Medical School, Boston, USA) for supplying TnphoA prior to publication, to M. Casadaban (Chicago, USA) for miniMu d lac, and to C. Gutierrez and D. Boyd (Harvard Medical School) and A. Wright and C. Hoffman (Tufts Medical School, Boston, USA) for helpful discussions concerning phoA gene fusions. This work was supported by grants from the Centre National de la Recherche Scientifique (UA04 1149 and ATP CP96) and from the Ministère de la Recherche et de la Technologie (82 V 1279).

\section{REFERENCES}

Benson, S. A., Hall, M. N. \& Silhavy, T. J. (1985). Genetic analysis of protein export in Escherichia coli K12. Annual Review of Biochemistry 54, 101-134.

BROCKMAN, R. W. \& HePPEL, L. A. (1968). On the localization of alkaline phosphatase and cyclic phosphodiesterase in Escherichia coli. Biochemistry 7, 2554-2562.

Castilho, B. A., Olfson, P. \& Casadaban, M. J. (1984). Plasmid insertion mutagenesis and lac gene fusion with Mini-Mu bacteriophage transposons. Journal of Bacteriology 158, 488-495.

Cavard, D., Bernadac, A., Pages, J.-M. \& LazDUNSKI, C. (1984). Colicins are not transiently accumulated in the periplasmic space before release from colicinogenic cells. Biology of the Cell 51, 7986.

Cavard, D., Lloubes, R., Morlon, J., Chartier, M. \& LAZDUNSKI, C. (1985). Lysis protein encoded by plasmid ColA-CA31. Gene sequence and export. Molecular and General Genetics 199, 95-100.

Chan, P. T., Ohmori, H., Tomizawa, J. \& Lebowitz, J. (1985). Nucleotide sequence and gene organization of ColE1 DNA. Journal of Biological Chemistry 260, 8925-8935.

Cole, S. T., Saint-Joanis, B. \& Pugsley, A. P. (1985). Molecular characterization of the colicin E2 operon and identification of its products. Molecular and General Genetics 198, 465-472.

Douglas, M. G., Geller, B. L. \& Emr, S. D. (1984). Intracellular targeting and import of $\mathrm{F}_{1}$ ATPase $\boldsymbol{\beta}$ subunit- $\beta$-galactosidase hybrid protein into yeast mitochondria. Proceedings of the National Academy of Sciences of the United States of America 81, 39833987.

Felmlee, T., Pellet, S., Lee, E.-Y. \& Welch, R. A. (1985). Hemolysin is released extracellularly without cleavage of a signal peptide. Journal of Bacteriology 163, 88-93.

HakKaART, M. J. J., VeltKamp, E. \& NiJKamp, H. J. J. (1981). Protein $\mathrm{H}$ encoded by plasmid CloDF13 involved in lysis of the bacterial host. I. Localisation of the gene and identification and subcellular localisation of the gene $\mathrm{H}$ product. Molecular and General Genetics 183, 318-325.

HAY, R., BöHNI, P. \& Gasser, S. (1984). How mitochondria import proteins. Biochimica et biophysica acta 779, 65-87.

Hirst, T. R., SANChez, J., Kaper, J. B., Hardy, S. J. S. \& Holmgren, J. (1984). Mechanisms of toxin secretion by Vibrio cholerae investigated in strains harboring plasmids that encode heat-labile enterotoxins of Escherichia coli. Proceedings of the National Academy of Sciences of the United States of America 81, 7752-7756.

HofFMAN, C. \& WRIGHT, A. (1985). Fusion of secreted proteins to alkaline phosphatase: an approach for studying protein secretion. Proceedings of the National Academy of Sciences of the United States of America 82, 5107-5100.

Hurt, E. C., Pesold-Hurt, B. \& Schatz, G. (1984). The amino-terminal region of an imported mitochondrial precursor polypeptide can direct cytoplasmic dihydrofolate reductase into the mitochondrial matrix. EMBO Journal 3, 3149-3156.

JAKES, K. S. \& Zinder, N. D. (1984). Plasmid ColE3 specifies a lysis protein. Journal of Bacteriology 157, 582-590.

LORY, S., TAI, P. C. \& DAVIS, B. D. (1983). Mechanisms of protein excretion by Gram-negative bacteria: Pseudomonas aeruginosa exotoxin A. Journal of Bacteriology 156, 695-702.

LAWRence, G. M. P. \& JAMES, R. (1984). Characterization of the ColE8 plasmid, a new member of the group E colicin plasmids. Gene 29, 145-155.

Maniatis, T., Fritsch, E. F. \& SambrooK, J. (1982). Molecular Cloning, A Laboratory Manual. Cold Spring Harbor, NY: Cold Spring Harbor Laboratory.

Manoll, C. \& Beckwith, J. (1985). TnphoA: a transposon probe for protein export signals. Proceedings of the National Academy of Sciences of the United States of America 82, 8129-8133.

Michaelis, S., Gurante, L. \& Beckwith, J. (1983). In vitro construction and characterization of phoAlac Z gene fusions in Escherichia coli. Journal of Bacteriology 154, 356-365.

MilleR, J. H. (1972). Experiments in Molecular Genetics. Cold Spring Harbor, NY: Cold Spring Harbor Laboratory.

NossaL, N. G. \& Heppel, L. A. (1966). The release of enzymes by osmotic shock from Escherichia coli in exponential phase. Journal of Biological Chemistry 241, 3055-3062.

Oudega, B., Stegehuis, F., Van Tiel-Menkveld, G. J. \& De Graaf, F. K. K. (1982). Protein H encoded by plasmid CloDF13 is involved in excretion of cloacin DF13. Journal of Bacteriology 150, 1115-1121. 
Pugsley, A. P. (1984a). Genetic analysis of ColN plasmid determinants for colicin production, release and immunity. Journal of Bacteriology 158, 523529.

Pugsley, A. P. (1984b). The ins and outs of colicins. Part I: production and translocation across membranes. Microbiological Sciences 1, 168-175.

Pugsley, A. P. (1985). Escherichia coli K12 strains for use in the identification and characterization of colicins. Journal of General Microbiology 131, 369376.

Pugsley, A. P. \& Rosenbusch, J. (1981). Release of colicin E2 from Escherichia coli. Journal of Bacteriology 147, 186-192.

Pugsley, A. P. \& Schnaitman, C. A. (1979). Factors affecting the electrophoretic mobility of major outer membrane proteins of Escherichia coli in polyacrylamide gels. Biochimica et biophysica acta 581, 163178.

Pugsley, A. P. \& Schwartz, M. (1983). A genetic approach to the study of mitomycin-induced lysis of Escherichia coli $\mathrm{K}-12$ strains which produce colicin E2. Molecular and General Genetics 190, 366-372.

Pugsley, A. P. \& Schwartz, M. (1984). Colicin E2 release : lysis, leakage or secretion? Possible role of a phospholipase. EMBO Journal 3, 2393-2397.

Pugsley, A. P. \& Schwartz, M. (1985). Export and secretion of proteins by bacteria. FEMS Microbiology Reviews 1, 3-38.

Raibaud, O., Mock, M. \& Schwartz, M. (1984). A technique for integrating any DNA fragment into the chromosome of Escherichia coli. Gene 29, 231241.
Schoemaker, J. M., Brasnett, A. H. \& Marston, F. A. O. (1985). Examination of calf prochymosin accumulation in Escherichia coli: disulphide linkages as a structural component of prochymosin-containing inclusion bodies. EMBO Journal 4, 775-780.

Tommassen, J., Pugsley, A. P., Korteland, J., Verbakel, J. \& LUGTENBERG, B. (1984). Gene encoding a hybrid OmpF-PhoE pore protein in the outer membrane of Escherichia coli K-12. Molecular and General Genetics 197, 503-508.

TOMMASSEN, J., LeUNISSEN, J., VAN DAMME-JoNGSTEN, M. \& OVerduIN, P. (1985). Failure of E. coli K-12 to transport PhoE-LacZ hybrid proteins out of the cytoplasm. EMBO Journal 4, 1041-1047.

Vernet, T., LaU, P. C. K., Narany, S. A. \& Vinsentin, L. P. (1985). A direct selection vector derived from pColE3-CA38 and adapted for foreign gene expression. Gene 34, 87-93.

WALKER, G. C. (1984). Mutagenesis and inducible responses to deoxyribonucleic acid damage in Escherichia coli. Microbiological Reviews 48, 60-93.

WATSON, R. J., LAU, P. C., Vernet, T. \& Vinsentin, L. P. (1984). Characterization and nucleotide sequence of a colicin-release gene in the hic region of ColE3-CA38. Gene 29, 175-184.

Yamade, M. \& NAKAZAWA, A. (1984). Factors necessary for the export process of colicin E1 across cytoplasmic membrane of Escherichia coli. European Journal of Biochemistry 140, 249-255.

Zhang, S., Faro, A. \& Zubay, G. (1985). Mitomycininduced lethality of Escherichia coli cells containing ColE1 plasmid: involvement of the kil gene. Journal of Bacteriology 163, 174-179. 